\title{
Music next to Theology: The Impact and Influence of Martin Luther's Reformation on Johann Sebastian Bach
}

James H. Ryan

Cedarville University, jhryan@cedarville.edu

Follow this and additional works at: https://digitalcommons.cedarville.edu/musicalofferings

Part of the Fine Arts Commons, and the Musicology Commons

DigitalCommons@Cedarville provides a publication platform for fully open access journals, which means that all articles are available on the Internet to all users immediately upon publication. However, the opinions and sentiments expressed by the authors of articles published in our journals do not necessarily indicate the endorsement or reflect the views of DigitalCommons@Cedarville, the Centennial Library, or Cedarville University and its employees. The authors are solely responsible for the content of their work. Please address questions to dc@cedarville.edu.

\section{Recommended Citation}

Ryan, James H. (2019) "Music next to Theology: The Impact and Influence of Martin Luther's Reformation on Johann Sebastian Bach," Musical Offerings: Vol. 10 : No. 2 , Article 3.

DOI: 10.15385/jmo.2019.10.2.3

Available at: https://digitalcommons.cedarville.edu/musicalofferings/vol10/iss2/3 


\title{
Music next to Theology: The Impact and Influence of Martin Luther's Reformation on Johann Sebastian Bach
}

\section{Document Type}

Article

\begin{abstract}
The artistic figure and music of Johann Sebastian Bach looms large in the history of Western arts and culture. His influences were many, but one strong influence in his life's work was that of the Protestant Reformation and the theology of the Lutheran church. Through this research, it is evident that Bach strongly held to the doctrines and theology of the Lutheran church and that his employment in the Lutheran church was not merely a vocation for him, but an outward expression of his inward religious and theological conviction. This position is evidenced by the writings and teachings of Martin Luther, specifically his writings on music. In these writings, Luther argues that music and theology are complementary of one another, and that music in the church is one of the strongest ways through which to communicate theology and the truth of scripture. The practice of the Lutheran church also suggests that Bach had a strong understanding of Lutheran theology, specifically the Lutheran catechisms. Finally, in the sacred works of Bach himself, specifically his cantatas, the theology of the Lutheran church and the religious conviction of the Protestant Reformation can be clearly observed. This research has been assembled through the study of historical documentation in the form of primary and secondary sources.
\end{abstract}

\section{Keywords}

J.S. Bach, Martin Luther, Reformation, theology, Lutheran, worship, religion

\section{Creative Commons License}

\section{c) (i) $९$}

This work is licensed under a Creative Commons Attribution-Noncommercial-No Derivative Works 4.0 License. 


\title{
Music next to Theology: The Impact and Influence of Martin Luther's Reformation on Johann Sebastian Bach
}

\author{
James H. Ryan \\ Cedarville University
}

wo hundred and sixty-nine years after the death of Johann
Sebastian Bach, his name is still recognized, and he is regarded
as one of the greatest, if not the greatest, musical composers of all time. His impact on the arts and on music specifically is unquestionable. Although his musical contributions were both sacred and secular, perhaps one of his most impressive bodies of work is that of his sacred music. A church employee as a Lutheran cantor for many years of his life, part of Bach's job was to write a new cantata for performance every Sunday. This imposing quantity of music written for the church naturally calls into question what Bach himself thought of the church and of God. Was Bach merely a musician employed by the church who wrote exceptional sacred music, or was he a theologian of sorts as well? The following research makes it evident that Bach was, in fact, more than just a musician. A member of the Lutheran church, Bach was strongly knowledgeable in theology as well as heavily influenced by the Reformation and Martin Luther. In Bach's day, the Reformation was nearing two hundred years old and still shaping the music culture. Thus, in order to truly understand the theology and music of the Lutheran church, and in turn, Johann Sebastian Bach, one must begin with the founder of the Lutheran church and one the great reformers, Martin Luther.

\section{Martin Luther: Music next to Theology}

When people think of the Reformation, many names may come to mind, but Martin Luther's rises to the top as the very first father of the Reformation. Luther's theology extended to many different fields,

Musical Offerings 10, no. 2 (2019): 81-91

ISSN 2330-8206 (print); ISSN 2167-3799 (online)

(C) 2019, James H. Ryan, licensed under CC BY-NC-ND

(http://creativecommons.org/licenses/by-nc-nd/4.0/) 
including concepts such as the Virgin Mary, monasticism, private confession, communion, and music. His views on music are clearly pertinent to this topic. Unlike John Calvin, Luther held broader views on the use of music, both instrumental and vocal, in the worship service. Luther famously said of music: "Music is next to theology." This quote is seen many different times and in many different contexts throughout his writings. ${ }^{1}$ For him, music was a medium through which to communicate the truth of scripture in art form. What he believed to be a tight-knit relationship between music and theology was essential to his theological methodology because music provided an alternative route through which fundamental theology could be taught and expounded. Music in the church, then, had the primary function of proclaiming the Gospel - to be the viva voce evangelii, or the living voice of the Gospel. ${ }^{2}$

For Luther, music was not only a means through which to communicate the Gospel, but it was also a means of response to the Gospel. In other words, he considered music to be the only natural human response to Christ's saving work. Music was a gift of God, able to create joyful hearts, drive away the devil, produce delight, and usher in peace. For proof of this, Luther pointed to the Psalms: "And we see how David and all saints put their pious thoughts into verse, rhyme, and song." ${ }^{3}$ Luther clearly believed in the marriage of music and theology in the Christian life and church. Any perspective indicating that music and theology were mutually exclusive of each other within the church bearing Luther's name would not authentically represent the essential nature of Lutheran theology. It is clear that the church of Bach's employment did not fundamentally believe in a separation of music and theology. Thus, the Lutheran church would not have relied on the services of Bach if he did not have a proper understanding of Luther's theology and the church itself. If Bach had been hired in such a manner, his employment would have stood contrary to the very words of Luther when he said that music is next to theology. Rather, because of the tight-knit relationship between music and theology in the Lutheran church, it stands to reason that

\footnotetext{
${ }^{1}$ Timothy Wengert, ed., The Pastoral Luther: Essays on Martin Luther's Practical Theology (Grand Rapids, MI: 2009), 271-272.

${ }^{2}$ Robin A. Leaver, "Johann Sebastian Bach: Theological Musician and Musical Theologian," Bach 31, no.1 (2000): 19-20. http://www.jstor.org/stable/41640463.

${ }^{3}$ Ibid., 19.
} 
Bach's very employment is an indication that he had a strong comprehension of Lutheran theology.

As discussed, Luther was a theologian with a sound understanding of music. The church that grew out of his beliefs reflected that. Naturally, the next question is: what evidence of this union between music and theology is there in the life and works of Johann Sebastian Bach? After all, he was employed at Lutheran churches for many years of his life. Because of his role as cantor, there should be evidence in Bach's life and in his musical writing of this Lutheran belief that "music is next to theology."

\section{Bach the Theologian: His Background}

Johann Sebastian Bach was not a man ahead of his time. He did not look to the future, nor was he a musical trend-setter. In order to understand him properly, one must look not forward to what Bach was anticipating, but backward to what he was protecting. Thus, to fully comprehend the music, the theology, and the man that is Johann Sebastian Bach, we must consider his upbringing and education. Bach's Protestantism dates back to his fifteenth-century ancestors. Veit Bach, who lived from 1550 to 1619 , moved from Hungary to Germany to flee the persecution of protestants that came with the Hungarian Protestant CounterReformation. In Germany, he could live his protestant lifestyle without fear and play on his lute, which he called one of his greatest joys. In addition to Veit Bach, many of Bach's forefathers were protestant instrumentalists who lived in the German provinces of Thuringia and Saxony, which was the home of the Reformation. Throughout his life, Bach was faithful to the occupation of his ancestors who had also been musicians in the service of the protestant churches of Germany. In his article, "Bach's Religion," Gerhard Herz says: "Thus Johann Sebastian Bach's profession and religion were traditional in his family long before he was born. Bach's religion was so deeply embedded in the old Lutheran faith that no new trends, such as the Pietistic movement which in his time aroused the Protestants, could become a serious problem for him."4 Thus, it seems that Bach's mission was to preserve, protect, and defend the musical legacy of those who came before him.

\footnotetext{
${ }^{4}$ Gerhard Herz, "Bach's Religion," Journal of Renaissance and Baroque Music 1, no. 2 (1946): 124-125. http://www.jstor.org/stable/20528723.
} 
Not only was Bach's religious heritage saturated in Protestantism, but even his childhood education focused on Lutheran doctrine. As a child, Bach was a superior student at the Ohrdruf Lyceum, one of Thuringia's best schools which was renowned for its theological teaching. It was here that he learned from the Compendium locorum theologicorum, a work written by Leonhard Hutter in an effort to defend Luther's doctrine against the even more reformed Protestants. After his schooling at Ohrdruf, Bach moved to Lüneberg where he attended St. Michael's School. Here he studied more of the theology of Leonhard Hutter with a strong emphasis on Lutheran orthodoxy. Hutter's loyal following of Luther and traditional Lutheran orthodoxy made a strong impact on Bach, and he carried it with him throughout his life. Thus, even Bach's education speaks to his strong command of orthodox Lutheran theology. ${ }^{5}$

The fact that Bach did not neglect his religious heritage amid the significant social changes of the early eighteenth century is striking. The dawn of the Age of Enlightenment caused rationalism to be a very prevalent mindset during the time of Bach. It was in this time of heightened rational thought that clashes between science and religion began to surface, and different schools of Protestantism emerged within the church. This raises the question: even though Bach's ancestry and education pointed toward orthodox Lutheranism, was Bach influenced in his ideology by the social and religious turmoil caused by the Rationalism of the early eighteenth century? The answer seems to be a clear "no." In fact, Bach himself spoke out against the belief of Rationalism in his cantata No. 178 when he said, "Cease, now, tottering Reason, cease!" and later: "Reason wages war against faith." ${ }^{6}$ To synthesize these points, Herz says it best: "None of the attempts to see Bach's religion in another light than the orthodox Lutheran can be supported theologically. From Spitta to Terry, Bach biographers have shown convincingly that Bach does not transgress the realm of the confessional church."

\section{Bach the Theologian: His Library}

In addition to his family ancestry and education, one can learn a great deal about Bach's views and theology by looking at his library. One of the best ways to learn about a person is to look at what he reads. When

\footnotetext{
${ }^{5}$ Herz, “Bach's Religion,” 125-126.

${ }^{6}$ Ibid., 128-129.

${ }^{7}$ Ibid., 129.
} 
scholars examined the personal library of Bach after his death, they discovered that it contained many theological books. In fact, it looked more like the working library of a pastor or a theologian than it did the library of a great musician. It was also evident to the scholars that Bach held Luther and his writings in high esteem. Bach's library contained eighteen folio volumes of the writings of Martin Luther. Additionally, Bach owned the three-volume Calov commentary, which is considered to be an edition of Luther's works. He placed this momentous commentary alongside the other works by Luther in his library. ${ }^{8}$

While the fact that Bach owned many works by Martin Luther is interesting and helpful, there are other more concrete evidences of Bach's theological beliefs. One such example is a letter written by Salomon Deyling, who was superintendent and professor of theology in Leipzig during the time of Bach. The letter, which was written to the Consistory, states plainly that Bach had agreed to and signed the Formula of Concord. The actual document that Bach signed on May 13, 1723, provides even further evidence, as Bach signed the Formula of Concord not once, but twice. The first signature stated positively that he endorsed Lutheran doctrines, and the second signature stated negatively that he denied non-Lutheran beliefs. Robin Leaver synthesizes this: "Bach, therefore, was not required to be simply a musician but a church musician with a specific level of competence in Lutheran confessional theology." ${ }^{9}$ As church cantor, Bach was not only required to be competent in Lutheran theology, but to know the catechetical questions and be able to teach them. He was also responsible for providing music befitting of certain liturgical and homiletic contexts, each of which had its own individual theological distinction. ${ }^{10}$ Thus, Bach was heavily influenced by Luther and the theology of the Lutheran church, not just because he was a member at a Lutheran church, but because it was part of his job to teach its theology. Just as Luther was a theologian with a good understanding of music, so Bach was a musician with a good understanding of theology. ${ }^{11}$

At this point, evidence shows that Bach stood in the wake of the Reformation, firmly grounded in orthodox Lutheranism and the teachings of Martin Luther. It has been shown that in Lutheran doctrine,

\footnotetext{
${ }^{8}$ Robin A. Leaver, "Bach and Luther," Bach 9, no. 3 (1978): 11.

http://www.jstor.org/stable/41640057.

${ }^{9}$ Leaver, "Johann Sebastian Bach," 25.

${ }^{10}$ Ibid., 31.

${ }^{11}$ Leaver, "Bach and Luther," 9.
} 
music and theology are not two exclusively separate fields, but rather, are inextricably linked and are used to complement one another. As such, it has been demonstrated that Bach, through his family ancestry, upbringing, and education, was well versed not just in music, but also in Lutheran theology. Not only was he well versed in orthodox Lutheran theology, but he also used that theology as a lens through which to view and respond to the Enlightenment movement. Naturally, the next question is this: what evidence of Bach's theology exists in his music?

\section{Bach the Theologian: His Music}

Before answering this question, it is important to note that there is a noticeable time gap in history between the life of Bach and the life of Martin Luther. Luther died in 1546, 139 years before Bach was even born. Thus, the Reformation and the work that Luther had started in the early 1500s had only continued, grown, and changed by the time Bach was born. Even in the Lutheran church alone, there were orthodox Lutherans who were more conservative along with Lutherans who pushed away from the traditions of Lutheran orthodoxy as part of the Pietistic Lutheran movement. Thus, if Bach was truly well versed in Lutheran orthodoxy and did not yield to the Pietistic changes or another wave of Protestantism, it is expected that his writing should reflect the writings of Luther. In fact, when Luther nailed the Ninety-five Theses to the door of the Wittenberg Castle church, he did not initially plan to start a new church but to merely "reform" the old one, hence the name for the subsequent movement, the "Reformation." Even the Lutheran orthodoxy to which Bach held might not be exactly what Luther believed, but it is the stream of theology most closely related to Luther, both in content and in time frame. Thus, one would expect the connections to Luther in the music of Bach to be strong.

One of the best ways to observe these connections is to study Martin Luther's commentary on scripture, comparing the content and emphases of his exegesis with the writing of Bach. For example, Bach's Magnificat is taken directly from the song of Mary in the Gospel. Thus, if Bach did indeed read and was indeed influenced by Luther, connections should be made between Bach's setting of the scripture and Luther's writing on the scripture. Indeed, Michael Linton says in his article on this subject that there is "substantial internal evidence that major passages of the work are structured in accordance with Luther's exegesis of the Canticle. Here, 
Bach read the scripture, consulted Luther, and structured his music."12 Bach composed two versions of his Magnificat. The first was composed for Christmas Vespers in 1723, while the second version was completed in 1732. In the second version, Bach deleted four of the original movements in an effort to make the work more liturgically flexible. It is in the original 1723 version that Bach's study of Luther's commentary is most clearly perceived. ${ }^{13}$ According to Linton, Bach's study of Luther is evident in "metaphors used by Luther which find expression in Bach's work, formal decisions which emphasize specific passages in the Commentary, musical emphasis of particular words singled-out by Luther for discussion, [and the] inclusion of hymns and texts to which Luther specifically refers." ${ }^{14}$ The evidence of musical emphasis on particular words is the principle of text setting. ${ }^{15}$ For example, the last verse of the Magnificat mentions two people, Abraham and The Seed. Luther's commentary references these two people several times and explains that it is this "seed of Abraham" that is both the promise of God and the very fulfillment of that same promise. Bach echoes this emphasis on the "seed of Abraham" in his text setting by using a dotted rhythm to set the word "Abraham" apart from the rest of the text. This dotted rhythm is exclusively "assigned" to the word Abraham and appears consistently throughout the movement. At one point in the movement, the figure is emphasized by all five voices. Throughout the movement, the harmonies are more chromatic in nature compared to the rest of the piece. To summarize in Linton's words: "Thus, the verse's most important phrase according to Luther, 'to Abraham and his Seed,' is emphasized by Bach through (1) text repetition, (2) chromatic harmonization, and (3) a unique rhythmic figure."16

Similarly, in the second movement of the work, Bach emphasizes the words "Deo," meaning God, and "salutari," meaning salvation, through the use of melismas and repetition. Why such a strong emphasis on "God's salvation?" In his commentary, Luther writes: "Mary...calls God her Savior, or her Salvation, even though she neither saw nor felt that this was so, but trusted in sure confidence that He was her Savior and her salvation. This faith came to her through the work God had done within

${ }^{12}$ Michael Linton, "Bach, Luther, and the Magnificat," Bach 17, no. 2 (1986):

5. http://www.jstor.org/stable/41640262.

${ }^{13}$ Ibid.

${ }^{14}$ Ibid.

${ }^{15}$ Ibid., 8.

${ }^{16}$ Linton, "Bach, Luther, and the Magnificat," 9. 
her. And, truly, she sets things in their proper order when she calls God her Lord before calling Him her Savior, and when she calls Him her Savior before recounting His works." ${ }^{17}$ This observation is of immense value in the theology of Martin Luther. One of the primary reasons that Luther nailed the Ninety-five Theses to the Wittenberg Castle church door was because the Catholic Church had placed too high of an emphasis on the works of the law in regard to salvation. Luther's decision only came when he searched the scriptures and saw that salvation was not through works of the law but through God justifying sinners through faith in Christ, and that faith being nothing more than a gift given by His own sheer grace. This is why Luther emphasized the principle of "God's salvation" in the Magnificat. It only supported his point all the more: salvation is not through works, but through justification by faith. Linton says this: "Mary exults in God her salvation. The emphasis of the text is not upon Mary's action, her exultation, but upon the source and end of the joy, God's salvation." ${ }^{18}$ Thus, Bach's text setting through melismas and repetition in this movement is a genius musical gesture that affirms Luther's conclusion. Through the music that he wrote, Bach was indeed affirming with Luther that salvation is of God, not of works.

The text setting does not stop there, however. In the fourth movement, "Omnes generationes," Bach employs a dense fugue. Of course, this is not unusual for Bach, but the method in which he writes this fugue is worthy of note. On every single beat, the fugue subject or fragments of the subject can be found somewhere in the musical texture. A fugue of this density is remarkable, but after reading Luther's thoughts on this portion of the scripture, Bach's compositional vision makes sense: "The Virgin Mary means to say simply that her praise will be sung from one generation to another so that there will never be a time when she will not be praised." 19 Thus, again Bach shows his mastery of text setting by creating a fugue movement in which the generations, represented by the various musical voices, continue without ceasing in their exultation. ${ }^{20}$

Thus, it is evident that, in the process of writing the Magnificat, Bach was not only a diligent student of Luther's commentary on the scripture,

\footnotetext{
${ }^{17}$ Linton, "Bach, Luther, and the Magnificat," 9-10.

${ }^{18}$ Ibid., 10.

${ }^{19}$ Ibid., 11.

${ }^{20}$ Ibid.
} 
but he actively sought to compositionally portray and affirm the principles and ideas of Luther. As Linton states, "There would seem to be no other reasonable explanation of the parallels. His music was thus purposefully a highly informed exegesis of the scripture according to Luther."21

The Magnificat is not the only piece in which Bach supports and affirms the teaching of Luther and the Lutheran tradition. Another example can be found in Bach's St. John Passion. The work focuses on the suffering of Christ on the cross with a hope toward the resurrection. This is an important doctrine in Lutheranism; in fact, Lutheran tradition has a special emphasis on the Crucifixion as being both the physical location of Christian redemption and the means by which that same redemption is secured. ${ }^{22}$ The cross in Lutheranism represents the humiliation of Christ but also provides the occasion for Christ's future resurrection and triumph over death. This important Lutheran doctrine did not escape Bach's notice as he wrote St. John Passion. Again, he employed compositional techniques to communicate this powerful Gospel picture. Bach creates a tonal motion that follows the trajectory of Christ. The work descends in flats to the crucifixion, symbolizing Christ making himself low and being humiliated. At the cross, the trajectory changes, and the work ascends in sharps for its remainder, symbolizing the cross as a lifting up of the glorious Christ and the future resurrection. ${ }^{23}$

\section{Conclusion}

In all these things, it becomes evident that Bach was not merely a musician employed by the church. His family ancestry and history were rooted in German Protestantism and the music of the Lutheran church. Bach was not just aware of Lutheran theology, but as church cantor, he was intimately knowledgeable of it through the catechisms. Bach's library included many of the writings of Luther, and evidence indicates that Bach was a devoted student of his work. Finally, in the very music of Bach, it is evident that through various compositional methods, Bach took a firm stance in musically exalting and affirming the doctrines and teachings of Protestantism, the Lutheran church, and Martin Luther.

\footnotetext{
21 Linton, "Bach, Luther, and the Magnificat," 13.

${ }^{22}$ Todd Breyfogle, "Redemption and Human Freedom in the Bach Passions," New Blackfriars 84, no. 989/990 (2003): 335-336. doi:10.1111/j.1741-2005.2003.tb06307.x. ${ }^{23}$ Ibid., 340.
} 


\section{Bibliography}

Breyfogle, Todd. "Redemption and Human Freedom in the Bach Passions." New Blackfriars 84, no. 989/990 (2007): 335-345. doi:10.1111/j.1741-2005.2003.tb06307.x.

Dürr, Alfred. The Cantatas of J.S. Bach. Revised and translated by Richard D.P. Jones. New York: Oxford University Press, 2005.

Forkel, Johann Nikolaus. Johann Sebastian Bach: His Life, Art, and Work. Translated by Charles Sanford Terry. New York: Vienna House, 1974.

Gardiner, John Eliot. Bach: Music in the Castle of Heaven. New York: Alfred A. Knopf, 2013.

Herz, Gerhard. "Bach's Religion." Journal of Renaissance and Baroque Music 1, no. 2 (1946): 124-138. http://www.jstor.org/stable/20528723.

Leaver, Robin A. "Bach and Luther." Bach 9, no. 3 (1978): 9-12. http://www.jstor.org/stable/41640057. . "Johann Sebastian Bach: Theological Musician and Musical Theologian." Bach 31, no. 1 (2000): 17-33. http://www.jstor.org/stable/41640463.

Lederer, Victor. Bach's St. Matthew Passion. Magnum Opus Series. Edited by Robert Levine. New York: The Continuum International Publishing Group, Inc., 2008.

Linton, Michael. "Bach, Luther, and the Magnificat." Bach 17, no. 2 (1986): 3-15. http://www.jstor.org/stable/41640262.

Mellers, Wilfrid. Bach and the Dance of God. New York: Oxford University Press, 1981.

Milner, Scott C. "'Süße Todesstunde' or 'Mit Fried und Freud:'

Reformation Theology and the Lutheran 'Art of Dying' in Two Bach Cantatas." Bach 31, no. 1 (2000): 34-57.

http://www.jstor.org/stable/41640464.

Noll, Mark. "Singing the Word of God." Christian History \& Biography 1, no. 95 (2007): 15-19.

http://search.ebscohost.com/login.aspx?direct=true \&db=f5h\& $\underline{\mathrm{AN}}=26329211 \&$ site $=$ eds-live.

Oberman, Heiko A. The Impact of the Reformation. Grand Rapids,

MI: William B. Eerdmans Publishing Company, 1994.

Rathey, Markus. Bach's Major Vocal Works: Music, Drama, Liturgy.

New Haven: Yale University Press, 2016. 
Schoenbohm, Richard. "Music in the Lutheran Church before and at the Time of J. S. Bach." Church History 12, no. 3 (1943): 195209. doi: $10.2307 / 3160092$.

Shute, Benjamin. Sei Solo: Symbolum? The Theology of J.S. Bach's Solo Violin Works. Eugene, OR: Pickwick Publications, 2016.

Spitta, Philipp. Johann Sebastian Bach. Translated by Clara

Bell and J.A. Fuller-Maitland. 3 vols. New York: Dover Publications, Inc., 1951.

Turner, Geoffrey. "Singing the Word: The Cantatas of J.S. Bach." New Blackfriars 87, no. 1008 (2006): 144-154. doi:10.1111/j.00284289.2006.00135.x.

Wengert, Timothy J., ed. The Pastoral Luther: Essays on Martin Luther's Practical Theology. Grand Rapids, MI: William B. Eerdmans Publishing Company, 2009.

Wolff, Christoph. Johann Sebastian Bach: The Learned Musician. New York: W. W. Norton and Company, Inc., 2000. 